\title{
ERRATUM
}

Metin Gürses · Özgür Sarığlu

\section{Accelerated Levi-Civita-Bertotti-Robinson metric in $D$ dimensions}

Published online: 29 March 2006

(c) Springer Science and Business Media Inc., New York 2006

\section{Gen. Relativ. Gravit.}

DOI: $10.1007 / \mathrm{s} 10714-005-0176-\mathrm{y}$

Issue: Volume 37, Number 12

Date: December 2005

Pages: 2015-2022

In the online version of this article, affiliations for one author was incorrect. The correct information is given below

The online version of the original article can be found at http://dx.doi.org/10.1007/s10714-005-0176-y

M. Gürses $(\bowtie)$

Department of Mathematics, Faculty of Sciences, Bilkent University, 06800, Ankara, Turkey

E-mail: gurses@fen.bilkent.edu.tr

Ö. Sarığlu $(\varangle)$

Department of Physics, Faculty of Arts and Sciences, Middle East Technical University,

06531 Ankara, Turkey

E-mail: sarioglu@metu.edu.tr 